\title{
Liability of school governing bodies: a legislative and case law analysis
}

\author{
E SERFONTEIN
}

\begin{abstract}
Through an in-depth analysis of legislation and case law, as important sources of education law, this article casts light on the liabilities School Governing Bodies may incur whilst exercising their statutory functions. Focus is placed on the legislative framework in which school governance occurs as cooperative government not only challenges the manner in which power is exercised, but also the empowering statute in itself. To illustrate the dichotomy that exists between the ideals of democratic policies and the manner in which they are interpreted and implemented, emphasis is placed on the practical implication of democratic governance in public schools with reference to important concepts such as representation, partnerships, accountability and liability. These concepts are critically analyzed in deliberation with court rulings in order to ascertain a better understanding of the important role School Governing Bodies have to play in striving to turn South African public schools into thriving centres of excellence.
\end{abstract}

Keywords: governance, cooperative government, statutory power, authority, partnership, organs of state, juristic persons, representation, responsibility, accountability, liability.

Disciplines: Law, Education and Public management and governance.

\section{Introduction}

The Constitution of the Republic of South Africa Act 108 of 1996 (Constitution), through section 29, grants everyone in South Africa the fundamental right to a basic education while obliging the State to respect, protect, promote and fulfil this right (section 7). Since education, as pointed out by Bray (2002:514), is vitally important for meaningful human existence, the State is bequeathed with an enormous duty in this regard.

Given the vastness of the task, Beckmann (2006:182) emphasizes that the State alone cannot provide a high quality of education to all. To lighten the State's burden, the Constitution provides, inter alia, for the establishment of organizations of structures and institutions (sections 91\&92) as well as the distribution of its functions (section 104). Basic education has, accordingly, been designated as a concurrent functional area for which both national and 
provincial governments are responsible while complying with the constitutional principles of cooperative government when exercising their authority over education (section 40(2)). In Ex Parte Chairperson of the Constitutional Assembly ${ }^{1}$ the Constitutional Court stated that cooperative government is implicit in any system where the same powers have been allocated to different levels of government.

The South African Schools Act, 84 of 1996 (Schools Act), consequently, proposes a partnership between the State, parents, educators and learners concerning the funding, governance and organization of schools which led to the creation of public School Governing Bodies (SGBs). By devolving powers and concomitant responsibilities, the State ensures, as avowed by Visser (2003:340), the fulfilment of the right to a basic education at a macro level through the provision of schools by provincial authorities and at a micro level through SGBs exercising their statutory powers. An important consequence of the latter is, as asserted by the court in Randpark $B p k v$ Santam Versekeringsmaarskappy, ${ }^{2}$ that the State will still be legally liable for the actions of these institutions as education is, first and foremost, a State responsibility.

Although decisions are to be taken by SGBs in a system of education containing centrally determined goals, priorities and frameworks for accountability (Caldwell \& Spinks, quoted by Mestry, 2006:28) they are nevertheless, per se put under pressure of public accountability (Ngidi, 2004:260).

This new educational system was considered by the court in the matter of Schoonbee ${ }^{3}$ to be $a$ migration from a system where schools were entirely dependent on the assistance of the State to a system where greater responsibility and accountability are assumed. It was, in addition, regarded in Christian Education South Africat as a radical break with an authoritarian past.

Since the concept of public School Governing Body is relatively new in South Africa, much has, thus far, been written on their functions, while few studies have been conducted on the liabilities which stem from such functions. Studies have identified a number of reasons which would account for these bodies' failure to conduct their functions successfully. Reasons provided for the latter include a lack of understanding regarding the extent of powers, responsibilities and liabilities whilst being unsure - notwithstanding especially section 60 of the Schools Act - of which support the State will provide.

\section{A legislative framework}

In terms of South African legislation more powers are allocated to SGBs. These powers are, according to Clase et al. (2007:248), reflected in the fact that SGBs legally have the power to establish the overall character and ethos of public schools. Most significant hereof, is the democratic governance of schools - centrally concerned with the distribution of powers (Maile, 2002:326) - through the active involvement of all role-players, which, according to Harber

1 Ex Parte Chairperson of the Constitutional Assembly: in re Certification of the Constitution of the RSA 1996(4) SA 744 (CC) para 287-290

2 Randpark Bpk.v Santam Versekeringsmaatskappy Bpk. 1965 b(4) SA 363 (A)

3 Schoonbee and Others v MEC for Education, Mpumalanga and Another 2002 (4) SA 877 (T)

$4 \quad$ Christian Education South Africa v Minister of Education 2000 (4) SA 757 (CC) 
(2005) as well as the High Court and Constitutional Court in the matters of Mikro and Pillay, ${ }^{6}$ respectively, relates the emergence of wider issues of democracy and participation.

Flowing from the above, it is apparent that legislation has dramatically altered the role of parents, as the majority members of SGBs, regarding education. Their traditional community support role is turned into a real governance and leadership role to which immense responsibilities are linked. The latter was affirmed by the High Court in the matter of Kimberley Girls' High, ${ }^{7}$ by stressing that vast obligations are coupled to the new powers allocated to SGBs.

As creatures of statute, specific powers, functions and legal obligations of SGBs are determined and demarcated by the Schools Act (sections 5-9). Section 20(1)-functions deal with, inter alia, responsibilities in respect of the best interests of schools comprising the development of school documentation, the support of staff, and the managing of administrative matters. Assigned section 21-functions, with direct financial implications, in contrast, are allocated only to SGBs after they have shown proof that they possess the power to perform such functions. Read together with section 22, providing for the withdrawal of SGB functions, this may, according to Visser (2003:111), be an attempt to limit legal powers.

The scope of section 21-functions was dissected in the matter of St Helena Primary School. ${ }^{8}$ While the SGB contended that such functions only confer powers on SGBs, the Department of Education (DoE) argued that they are coupled with obligations to, in this case, maintain school buildings. Since this matter concerned damages caused by an isolated incident - fire to the library, - the High Court refused to elucidate on the administration of education services in general. It was, however, decided that the Department was not unjustly enriched and the SGB not impoverished by the latter paying for the repair of the buildings out of the proceeds of an insurance policy.

This decision has elicited criticism from academics. Schlemmer and Sonnekus (De Bruin 2009a), for instance, opine that, since the State owns them, it carries the constitutional duty to insure school buildings. Insurance companies may refuse to pay SGBs for damages in this regard as they cannot suffer damages as they are not the owners thereof. It is hence argued that if the State does not insure school buildings, SGBs may be required to increase school fees to pay for expensive insurance policies.

As juristic persons, public schools have the legal capacity to perform their functions. Acting through their SGBs, public schools acquire rights and incur responsibilities and liabilities attached to their status (Visser 1998). It was, accordingly, ruled by the Court? in Grove Primary School $v$ Minister of Education ${ }^{9}$ that SGBs indeed enjoy locus standi in courts. This was confirmed

5 Mikro Primary School v Minister of Education, Western Cape 20053 SA 504 (C)

6 MEC for Education, KwaZulu-Natal, and others v Pillay 2008 (1) SA 474 (CC)

$7 \quad$ Kimberley Girls' High School and another v Head Department of Education, Northern Cape Province and others. 2005 (5) SA 251 (NC).

8 St Helena Primary School and another v The MEC: Department of Education Free State Province and another, Case No. A 3/07. High Court of South Africa: Orange Free State Provincial Division.

9 Grove Primary Schoolv Minister of Education and others 1997 (4) SA 982 (C)

TD, 6(1), July 2010, pp. $93-112$. 
in the matter of Bestuursraad van Laerskool Sentraal, Kakamas, ${ }^{10}$ as the High Court held that SGBs are able to sue parents for outstanding school fees (Schools Act: section 40(1)). SGBs can, however, also be sued if not complying with their duties. In the matter of Hunt Road Secondary School ${ }^{11}$ the High Court, for example, had to coerce the SGB to implement their obligations in terms of section 41, regarding the total or partial exemption of parents from paying school fees.

Notwithstanding, Gamage (1994:47) opines that the devolution of power will lead to healthier relationships and provide an alternative form of accountability to bureaucratic surveillance. This is based on the hypothesis that, when educators and communities collaborate, mutual responsibilities will grow from it.

In support, Maile (2002:327) states that education services constitute an interlocking set of powers and duties, and can, as a result, only work effectively if all role-players grasp their responsibilities and act accordingly. Emanating from the latter, Clase et al. (2007:244) emphasize that a balance must be struck between the authority of the State and that of SGBs.

\section{School governance}

Although the Schools Act (section 16(1)) entrusts the governance of schools to SGBs, no definition is afforded to the term governance (Visser 2003:111). Mere guidelines for the distribution of power and only sketchy assistance in the division of authority are provided (Van Wyk 2004:53). As a result, a dichotomy exists between the ideals of democratic policies and the manner in which they are interpreted and implemented (Fareed \& Waghid 2005:25).

Governance must, thus, be defined by studying different interpretations thereof. In the matter of Grove Primary School ${ }^{2}$ the Court avowed that governance simply replaces the words management, control and executive power as per section 31(1) of the Education Affairs Act 70 of 1988. According to Maile (2002:1) and Nigidi (2004:261), school governance is an act of determining policy and rules by which schools are to be organized. To Kuye and Kakumba (2008:632) governance refers to the manner in which power and resources are applied towards the realisation of objectives. Sound governance, consequently, entails the use of power in a manner that respects human rights, while promoting democracy and accountability.

A much broader definition is provided by the United Nation's Commission for Global Governance: governance refers to the sum of the ways institutions manage their common affairs. It is a continuing process through which conflicting or diverse interests may be accommodated and cooperative action may be taken. Accordingly, sound governance implies the creating of well-functioning and accountable institutions that citizens regard as legitimate, through which they participate in decisions that affect them, and by which they are empowered.

10 Die Bestuursraad van Laerskool Sentraal, Kakamas v Kranenburg en Izaks, Case No. CA\&R 52/07. High Court of South Africa: Northern Cape Division.

11 Centre of Applied Legal Studies, Audrey Ngubane and Emily Ngwira v Hunt Road Secondary School, The KwaZulu-Natal MEC for Education, the Minister of Education and the South African Human Rights Commission. Case No. 10091/2006 High Court of South Africa, Durban and Coast Local Division 
As the decentralization of governance implies that decision-making responsibilities have devolved from central government to self-governing school communities (Fareed \& Waghid 2005:25), it is evident, as stated by Kuye and Kakumba (2008:633), that governance is not a preserve of the State or the wielders of state power, but rather, a partnership between the leaders and the led to promote the entire society's well-being. Probyn et al. (2002:3), similarly, caution that it would be mistaken to view school governance as a simple hierarchical, linear process.

Constitutional principles for cooperative governance - envisaging cooperation, coordination, support and interdependence (Bray 2002:518) - rather include ensuring transparent and accountable governance, consulting on matters of mutual interest, and ensuring that agreed procedures are followed. Cooperative governance thus entails an interactive approach in which all role-players are represented and take co-responsibility for the efficient operations of schools (Van Wyk 2004:53). In this regard, Clase et al. (2007:244) stress that the vision aspired to by political leaders for education must be mutually shared by all. The authors, conversely, have reservations as to whether this is the case.

In the matter of Governing Body, Mikro Primary School ${ }^{3}$ the High Court had to decide whether an SGB is an organ of state and, as such, bound to constitutional principles of cooperative governance. The court concluded that, since the SGBs, as statutory bodies, are intended to be independent of State control, they are not organs of state. As such, the State was interdicted not to unlawfully interfere with the governance of the school. The High Court's decision was, however, overruled by the Supreme Court of Appeal ${ }^{14}$ who held that, since public schools and their SGBs are clearly institutions performing public functions (Constitution: section 239(b)(ii)), they are indeed organs of the state. The court a quo's decision to prevent the State from unlawfully interfering with the governance of the school was, nevertheless, upheld. Visser (2006:340), accordingly, criticizes the ill advised interference of the DoE in the functions of SGBs.

Although independence may be welcomed as recognizing the involvement of the broader community, Roos (2003:492) cautions that it could lead to the implementation of policies that do not comply with legal requirements. Due to the fact that SGB-members, with usually no legal training, are expected to draft rules that conform to intricate legal requirements, their independence may leave the decision as to the legality of rules to courts (Probyn et al. 2002:2). The latter is confirmed by Clase et al. (2007:246) showing that courts are increasingly asked to settle disputes between the DoE and SGBs.

In this regard, Bray (2002:524) refers to the Constitution compelling organs of state to make every reasonable effort to use appropriate procedures to resolve internal disputes and to exhaust all other remedies before turning to courts. The court, nevertheless, expressed; in the case of Douglas Hoërskool; ${ }^{15}$ that it will not hesitate to substitute its own decision for that of a functionary (DoE) who has discretion under an Act. The important role of courts was

14 Minister of Education, Western Cape v Governing Body, Mikro Primary School 2006 (1) SA 1 (SCA)

15 Douglas Hoërskool en ' $n$ ander v Premier, Noord-Kaap, en andere 1999(4) SA 1131 (NC) 
highlighted in the matter of Settlers Agricultural High, ${ }^{16}$ as the court indicated that it is in the interest of justice to resolve differences pertaining to the interpretation of educational provisions.

In view hereof, the key practical implications of bestowing more powers and responsibilities on SGBs will forthwith be addressed.

\section{Practical implications}

Emphasis placed on school governance brought along a new framework built on accountability, which, according to Maile (2002:326), strengthens the position of school managers and enables them to rather share educational power instead of losing it..

Within these parameters, school managers must reposition themselves to overcome rules driven by bureaucracy (Schelder et al. 1999). This is important since the democratization of schooling will be tenuous and remains policy rhetoric if all governance functions are not equally accessible and practiced in schools (Karlsson 2002:132). In practice, Mabaso and Themane (2002:111) as well as Mabovula (2009:219) point out that democratic school governance is inhibited by many underlying factors. Singh et al. (2004:301), for example, proclaim that parental participation is beset with problems and, according to Roos (2003:485), uncertainties which silence the voice of community partners in school matters. As a result, Clase et al. (2007:249) voice their concern over the lack of cooperation between educational role-players as it may seriously threaten the functioning of the entire education process.

\subsection{Representation}

In order to democratize school governance and transform schools into democratic institutions (Fareed \& Waghid 2005:25), membership of SGBs comprises democratically elected parents, educators, non-teaching staff and learners in the case of all mainstream secondary schools. This composition of SGBs, as representatives of the community, provides, as per the Supreme Court of Appeal in the matter of Hoërskool Ermelo, ${ }^{17}$ for the broad participation in decision-making processes with emphasis on the contributions by parents. Governance is, as such, based on the core democratic values of representation, participation, openness, tolerance, rational discussion, collective decision-making (Karlsson 2002:329) and accountability which, according to Heystek (2004:308), are paramount in the quest for the realization of the best interests of schools and the provision of quality education. Participation was regarded, in Doctors for Life $v$ Speaker of the National Assembly ${ }^{18}$ as to provide vitally to the functioning of representative democracy. In line, the United Nations' Development Program illustrates that inclusiveness in terms of equal participation, equal treatment and equal rights is a core value of democratic governance.

16 Head of Department, Department of Education Limpopo Province v Settlers Agricultural High School and Others (CCT36/03) [2003] ZACC 15; 2003 (11) BCLR 1212 (CC) (2 October 2003)

17 Hoërskool Ermelo \& School Governing Body of Hoërskool Ermelo v The HOD of Education: Mpumalanga and others. Case No. 219/2008. Supreme Court of Appeal: RSA 
The Human Rights Commission (Du Toit 2007) is, on the contrary, concerned about whether SGBs are indeed representative and, consequently, whether decisions taken are in the interests of the broader community. The latter is underscored by research conducted by Mncube (2009:93) which indicate that SGB-members often accept decisions taken by principles as they are afraid of being suspected of betrayal and, therefore, pretend to being involved in decisions. Xaba's (2004:315) research, correspondingly, identifies principals who dominate decision-making, while Probyn et al. (2002:3) found that SGBs implement policies due to political pressure rather than to conform to statutory functions. From another perspective, Mabovula (2009:220) reveals that senior learners are being excluded from participation in SGBs due to, among others, educators' domination.

\subsection{Partnerships}

The fact that the Schools Act, in giving effect to the ideal of partnerships, confers a considerable degree of autonomy in the governance of school affairs to SGBs was confirmed by the Supreme Court of Appeal in the matter of General Hendrik Schoeman Primary School. ${ }^{19}$ Fareed and Waghid, (2005:25) however, caution that mere participation by SGBs does not lead to democratic transformation as there are many variables that have to be considered to determine whether SGBs participation indeed contribute towards sustaining democratic principles.

In this regard, Mabovulo (2009:223) maintains that a key principle of school governance is that decisions be based on consultation, collaboration, cooperation, mutual trust and participation of all affected parties. All role-players should, thus, be permanently engaged in dialogue.

Although there is compelling evidence that school-family-community partnerships benefit learners, parents and schools (Singh et al. 2004:303), many educators still opine that legislation provides SGBs with too much power (Van Wyk 2001:115,121\&124). SGB-members, accordingly, are not accepted and treated as equal partners (Clase et al. 2007:246).

While FEDSAS (2002) endeavours to establish and maintain healthy relationships between all interested parties, many research results indicate the opposite. A study conducted by Mabasa and Themane (2002:111) found that serious challenges with respect to participation in SGBs remain evident. Challenges include the actual constitution of SGB-membership, divisive and competing interests served on SGBs, and the manner in which decisions are taken. Despite numerous calls on parents to get involved in education (Hoffman 2009), they remain reluctant to meet their obligations; lack interest and commitment, and avoid taking responsibility for and ownership of education.

There is, as such, still a need to make governance less overwhelming to SGBs by clarifying exactly what rights and liabilities are bestowed upon parents as members of SGBs and how to effectively deal with or prevent legal liability (Tsotsetsi et al. 2008:386).

This will, however, not be easy as parents are not well prepared for conforming with their new functions, finding expression in the following: unfamiliarity with meeting procedures; not knowing how to make a contribution; lacking knowledge of legislation; feeling inhibited by the presence of knowledgeable educators; and perceiving their role as simply rubber stamping what 
others have already decided upon (Mabasa \& Themane 2002:112; Heystek 2004:309; Mestry 2006:27-28; Mncube 2009:85\&93). Consequently, as put forward by Probyn et al. (2002:2), a mismatch between the dream and reality exists.

This mismatch is illustrated by the existence of power struggles between SGB-members, the DoE, school principals and even union members (Gouws 2001; Oelofse 2003; \& Rademeyer 2009). Despite conflict-solving being a prerequisite for democracy and social democracy predetermining consensus and the sharing of power which binds partners together (Fareed \& Waghid 2005:26), tension continues to exist amongst educational partners (Mabasa $\&$ Themane 2002:114).

Tension, according to Colditz (Basson 2003), arises, due to, inter alia, the State unilaterally containing the powers of SGBs and, therefore, interfering with the democratic execution of the will of parents. As a result, parents feel that government does not place much value on their partnership (Volksblad 2005).

An example of the aforesaid can be found in the matter of Laerskool Gaffie Maree ${ }^{20}$ where the High Court had to intervene between the DoE and an SGB in appointing a principal. Although the SGB recommended one person by providing a list of three names in terms of section 6 of the Schools Act, no appointment was made. While alluding to the circumstances under which recommendations could be declined by the DoE (section 6(3)(b)), the High Court had to remind the DoE that it is obliged to act within the confines of the law. It was also stressed that the DoE should respect the choice made by the SGB. The same stance was followed in the matters of Hartswater High School, ${ }^{21}$ The Point High School ${ }^{2}$ and High School Carnarvon. ${ }^{23}$

Another example of existing conflict between the DoE and an SGB occurred in the matter of Hoërskool Ermelo. ${ }^{24}$ The Supreme Court of Appeal clearly stated that this matter did not concern the language policy of schools per se but rather the principle of legality and the proper exercise of administrative powers in the sphere of education. As such, the court referred to the strife between the DoE and the SGB which led to the suspension of the principal, the withdrawal of the SGB's function to determine the school's language policy and, even to the dissuasion of the SGB; all of which the DoE had no right to. Under similar circumstances, the SGB of Hoërskool Hoopstad (Van Rooyen 2009) had to turn to the court for an interdict preventing the DoE to interfere with its admission and language policies.

20 Laerskool Gaffie Maree \& The Governing Body of the Laerskool Gaffie Maree v MEC for Education, Training, Arts and Culture: Northern Cape Province and HOD of Education, Training, Arts and Culture: Northern Cape Province. Case No. 1240/)1. High Court of South Africa: Northern Cape Division

21 Hartswater High School and Another v Head of the Department of Education: Northern Cape (765/2996) [2006] ZANCHC 67 (8 December 2006)

22 The Point High School and others v The HoD of the Western Cape Department of Education 2007 SCA $14188 / 06$

23 High School Carnarvon and another v MEC for Education, Training, Arts and Culture of the Northern Cape Provincial Government and another 1999 JOL 5726 (NC)

24 Hoërskool Ermelo \& School Governing Body of Hoërskool Ermelo v The HOD of Education: Mpumalanga and others. Case No. 219/2008. Supreme Court of Appeal: RSA 
The DoE also needed to be ordered by the court in FEDSAS $v$ MEC for Education, Gauteng ${ }^{25}$ to follow prescribed procedures with respect to the closure of schools and not just to negate the inputs of SGBs. In yet another case concerning conflict with regards to the expulsion of learners, to which the DoE allegedly showed and inflexible attitude and disclosed institutional biasness against expulsion as a remedy for serious misconduct, the High Court; in the matter of Queens College Boys High, ${ }^{26}$ claimed that such continuous and justiciable issues are regrettable.

A lack of cooperation with SGBs by the DoE can forthwith be illustrated by referring to the matter of Governing Body of Bopasetjab ${ }^{27}$ in which the court had to urge the DoE to consult with all role-players with regard to the erection or not of school buildings.

Following the above, it becomes evident that, while partnerships may provide all role-players a powerful voice in school affairs (Pennefather 2008:90-92), they also lead to large unprecedented demands and stresses (Clase et al. 2007:244). In line herewith, Beckmann and Prinsloo (2009:174) explain that educational partnership does not necessarily lead to democratic participation in practice. While participation is encouraged by the State, measures are simultaneously taken to limit the involvement and powers of SGBs. Partnerships, in addition, promote new expectations that need to be satisfied (Marope \& Sack 2007:27) which, as said by Clase et al. (2007:255), will not be an easy task due to lack of mechanisms to facilitate educational partnerships.

Since power play between role-players may have a detrimental effect on the relationship of trust and mutual support (Heystek 2004:310), and impact negatively on the participation of all in school governance (Mabasa \& Themane 2002:114), schools will have to create space for criticism amongst role-players. This is important as participants should not be coerced to put their differences aside to invoke a common goal, but rather to discuss them in order to find consensus (Mabovula 2009:219). Fareed and Waghid (2005), however, state that citizens of a democracy do not simply arrive at political maturity and stand ready, willing and able to run institutions, they have to be thoroughly trained to take up their responsibilities. In line, Zuma (Hoffman 2009) places emphasis on formal training being a pre-condition for principals in particular.

\subsection{Accountability}

Changes brought along by the Schools Act regarding school governance are, according to Ngidi (2004), to devolve more responsibilities to SGBs and, subsequently, to place SGBs under the pressure of public accountability.

25 Federation of Governing Bodies of South African Schools (Gauteng) v MEC for Education, Gauteng 20002(1) SA 660 (T)

26 Queens College Boys High School v MEC, Department of Education, Eastern Cape Government, Head of Dept of Education, Eastern Cape Province, A. S. and ten others: High Court of South Africa, Eastern Cape Division. Case No. 454/08

27 Governing Body of Bopasetjaba and other v Premier of the Free State Province and others (2238/2003) ZAFSHC 77

TD, 6(1), July 2010, pp. $93-112$. 
Accountability, an important but rather new principle in the realm of school governance, includes democratic control over administration and the right to legal protection. It implies that SGBs can be called upon to explain their policy-decisions, evaluate the impact of new rules and decisions and take responsibility for their actions (De La Harpe et al. 2008:17-18). The importance of accountability is highlighted by Maile (2002:326), indicating that it enhances partnerships and balances the power between partners. In support, Ngidi (2004) shows that accountability contributes to active involvement and efficiency, whilst Fareed and Waghid (2005:27) emphasize that it curtails the misuse of power by acting as a deterrent as it discourages irresponsible representation.

The accountability of SGBs to their constituencies is implicated by the Schools Act. Section 18(2)(b) provides for meetings with parents, learners, educators and other staff members whilst section 18(2)(e) obliges SGBs to render reports on their activities. Section (20)(9), in addition, provides for the presentation of annual financial reports. Notwithstanding, parents still complain about receiving no financial statements from schools (Rapport 2009).

Whether SGBs are exercising their authority accountably also had to be established by courts. In the matter of Pillay ${ }^{28}$ the SGB was, for example, held accountable for their Code of Conduct which was alleged to unfairly discriminate against a learner for not allowing her to wear a nose stud to school. Although both the Equality and High Courts found that the learner had not been discriminated against unfairly, the Constitutional Court ruled differently. The latter court decided that it was irrelevant whether the wearing of a nose stud was voluntary or mandatory, as schools are obliged to take steps to reasonably accommodate the needs of all learners. The Code of Conduct was criticized as it did not set realistic boundaries and did not provide procedures to be followed when applying for and granting exceptions.

In another case, Mose $v$ Minister of Education in the Provincial Government of the Western Cape, ${ }^{29}$ the SGB was called upon to defend the procedures they followed during suspending a learner and recommending that he be expelled. The court found in favour of the SGB as it had not exercised its authority in an arbitrary, capricious or irrational manner as alleged.

With regard to the fairness of administrative actions taken by SGBs, the court decided in $N d$ lovu $^{30}$ that the SGB failure to afford learners a hearing and thus not adhering to the requirements of natural justice, caused prejudice to individual learners. In line herewith, the SGB was held accountable and ordered to provide learners individually with an opportunity to be heard before instructing all to rewrite the biology exams.

Despite court intervention, Deem et al. (Ngidi 2004:260) argue that there are not enough mechanisms in place to make governors accountable to those whose interests they represent.

28 See fn 6

29 Mose v Minister of Education in the Provincial Government of the Western Cape: Gabru (13018/08) [2008] ZAWCHC 56 (13 October 2008)

$30 \quad$ Minister of Education and Training and others v Ndlovu 1993 (1) SA 89 (A) 


\subsection{Liability}

Liability can be incurred due to a contractual relationship between two parties or from a delict. When dealing with professional liability to clients, the possibility of a concurrence of claims based on delict and breach of contract respectively is always present. With reference to education, the concept professional liability can denote any form of liability incurred by a person or institution acting in a professional capacity (Van Aswegen 1997:407).

By providing juristic personality to public schools (Schools Act: section 15), the State denotes authority (capacity to conclude juristic acts on its behalf) to public schools (Wicke 1998:610). Together with the fact that public schools are organs of state, the State, as the principal, may be held vicariously liable for the actions of public schools, as agents.

South African law recognizes four categories of vicarious liability, determined according to the relationship between two parties. The relevant three relationships are (a) employer (State/SGB) and employee (Educators employed by the State/SGBs), (b) principal (State) and agent (public school), and (c) partners (role-players) with each other (Wicke 1998:611).

For the State to be held liable for the actions of SGBs it is, however, necessary that SGBs act within the limits of their authority (Wicke 1998:612). To this extent, SGBs are subject to control. Visser (2003:114), concurrently, stipulates that if SGBs act outside of their functions, such actions will be ultra vires and, in the event of contracts, will be null and void.

State liability for educational activities is provided for by the Schools Act through section 60 which, in relation to the Framesby-case ${ }^{31}$ equally applies to delictual and contractual liability and to the Southview High School ${ }^{22}$ and General Hendrik Schoeman Primary Schoo ${ }^{3}$-cases only to delictual liability.

The two forms of liability - that of contractual and delictual liability - will be dealt with separately.

\subsubsection{Contractual liability}

From the Schools Act as a whole, it may be concluded that the primary legal responsibility regarding the conclusion of contracts on behalf of schools vests in SGBs (Visser 2003). This Act does, unfortunately, not present a coherent and comprehensive set of principles clarifying all issues regarding the contractual capacity of SGBs.

In the matters of Gene Louw ${ }^{34}$ and Fish Hoek Primary Schoo ${ }^{35}$ the courts had to consider the nature of the legal relationship between public schools and their parents. The courts held that

31 Technofin Leasing \& Finance (Pty) Ltd.v Framesbury High School and The MEC for Education, Eastern Cape Province. Case No. 1073/2001. High Court of South Africa: South Eastern Cape Local Division.

32 Financial Services of SA (Pty) Ltd v Southview High School

33 See fn 18

34 Die Bestuursliggaam van Gene Louw Laerskool vs JD Roodman, Case No. A37/2000

35 Fish Hoek Primary Schoolv Gregory Welcome Case no A 154/08: Supreme Court of South Africa: Cape of Good Hope Provincial Division

TD, 6(1), July 2010, pp. $93-112$. 
contractual relationships exist between schools and parents and; that schools, providing services to learners, thus, have contractual claims against parents to, in casu, pay school fees. Flowing from the latter, Visser (2003:113) and Floyd (2005:387) confirm that the contractual capacities of SGB are wide enough to permit them to conclude contracts with others to perform acts of commercial nature which SGBs are entitled to perform on behalf of schools.

In deciding on who (State/SGB) should be held liable for contractual damages or losses suffered in connection with educational activities, the court referred to section 60 of the Schools Act in the case of Framesbury High School. ${ }^{36}$ It was established that, since SGBs are obliged to manage and control schools (Schools Act: section 16), the section 21-school in casu had the necessary power to enter into a contract to purchase school equipment, section 60 equally applies to delictual and contractual liability, the State had to accept its obligations in both instances.

In order for the State to be liable, the court placed emphasis on the limited scope of section 60, providing that the State can only be held liable if the SGB would have been liable, and the requirement of educational activity was met. Judge Pickering opined that the purpose of section 60 is, amongst others, to protect public schools which would, but for the provision of this section, have been liable for contractual damage or loss to others. If the latter is, to the contrary, caused in connection with a business for the purpose of supplementing school resources or relating to the SGB's contractual responsibility as employer (Schools Act: section 20(10)) the State would, however, not be held liable. The court found that, since a photocopier machine was required by the SGB in casu for its educational activities and since the SGB could be held liable, the State should be held liable in terms of the contract entered into by the SGB.

Under similar circumstances, the Constitutional Court was asked to decide on who should be held liable for the contractual obligations incurred by an SGB (buying a Photostat copier for the school) in the matter of General Hendrik Schoeman Primary School. ${ }^{37}$ While the Magistrate and High Court decided that the State should be held liable, the Supreme Court of Appeal held the school liable. The latter court concluded, contrary to the Framesby-decision, ${ }^{38}$ that the State could only be held delictualy liable for the actions of SGBs. The court alluded to the fact that section 60(1) does not exempt SGBs from liability to render specific performance of contractual obligations lawfully undertaken by the school's SGB on its behalf. The public school itself, and not the State, are therefore liable for the fulfilment of its contractual obligations. Contractual parties can, consequently, not rely on any warranty by the State that SGBs will perform their obligations contracted to. The reason for the latter, being that the Schools Act proposes a partnership between the State and SGBs in which both parties should take responsibility for their actions. The Constitutional Court's decision in this regard is, unfortunately, still awaiting (De Bruin 2009b).

Section 60 also came under the light in the matter of Strauss. ${ }^{39}$ An educator, employed by the SGB claimed for damages sustained while training learners to throw the discus. Strauss alleged that her injuries were caused due to the negligence of the school by failing to take the necessary reasonable steps (no safety nets were provided to ensure a risk-free environment) to prevent

$\begin{array}{ll}36 & \text { See fn } 30 \\ 37 & \text { See fn } 18 \\ 38 & \text { See fn } 30 \\ 39 & \text { MEC for Education, Western Cape Province v Strauss } 2008 \text { (2) SA } 366 \text { (SCA) }\end{array}$


injury. While it became evident that the SGB, and not the State, was to be held liable for the educator's injuries in terms of section 60(5) of the Schools Act, the court concluded that this section does not preclude claims, such as this, based on the State's own negligence and who has been cited as a wrongdoer. The State was, subsequently found to be blamed and, thus, held liable for the damages.

With regard to liability of SGB-members (in person) in terms of contracts on behalf of schools, Visser (2003:114) highlights that they cannot be held personally liable in terms of contracts since the intention are that the school would be bound. The members may, however, be held liable in delict on the basis of misrepresentation if their conduct has caused economic loss and if all requirements for such liability is present.

\subsubsection{Delictual liability}

Arising from the statutory functions allocated to SGBs, these bodies are obliged to carry out their duties (moral obligations or requirements). In this regard, Shaba (2000) indicates that any omission to perform such functions, subsequently, may result in delictual liability.

Due to the wide spectrum of functions allocated to SGBs and the vulnerability of their main clients (learners), it can easily happen that mistakes are made due to which injuries or damages to property occur. Mistakes made by SGBs could harm the reputation or interfere with the privacy of learners, educators, parents or members of the general public.

Conduct causing loss to another in general gives rise to a claim for damages in delict, provided the requirements for delictual liability are met. Subsequently, the State can incur liability for damages caused by educators or schools to others by conduct relating to the exercise of educational activities. Van Aswegen (1997:407), however, points out that legal subjects are free to regulate their legal position by agreement subject to generally applicable legal rules. This includes the freedom to exclude or limit the ambit of any form of liability arising between parties, including delictual liability and liability for breach of contract. Although good liability risk management can reduce the chances of being sued, it can, unfortunately, never eliminate risks entirely.

In order to absolve the DoE from liability, parents are often requested to sign indemnity forms. This was the case in the matter of $A z e^{40}$ in which a learner sustained serious injuries due to a motor vehicle accident whilst driving with an educator, in her own car, to a prearranged fieldtrip. The court found that, although the exemption contained in the indemnity form unambiguously pardoned the DoE from liability, the additional phrase to the indemnity, namely in the knowledge that the principal and his staff will, nevertheless, take all reasonable precautions for the safety and welfare of my child, qualified the indemnity to such an extent that it could not constitute a defense to the learner's claim for damages. Since the accident occurred due to the educator's negligence, the DoE was held liable.

With specific reference to the safety of learners, Pearmain (2006:293) points out that the Constitution obliges the State to create an overall environment that promotes the fulfilment of fundamental human rights as set out by the Bill of Rights. Although section 29 of the 
Constitution, on the face of it, only imposes a positive duty on the State to progressively realize human rights, it cannot be reasoned that the State alone must carry this burden. Given the fact that the State may impose duties upon others by way of legislation, SGBs are also responsible for creating flexibility as to how human rights are given effect to in practice. SGBs are, correspondingly, responsible for ensuring that the necessary policies are in place to ensure orderly school environments.

According to section 4.6 of the Guidelines for the Consideration of Governing Bodies in Adopting a Code of Conduct for Learners, they have a right to a clean and safe environment that is conducive to education. Creating safe school environments is, therefore, a prerequisite for the realization of equal educational opportunities and quality education to all.

Safe schools are defined by Squelch (2001:13) as those who are free of danger and possible harm; places in which non-educators, educators and learners can work, teach and learn without fear of ridicule, intimidation, harassment, humiliation and violence. Therefore, safe schools are healthy schools in that they are physically and psychologically safe. Indicators of safe schools include the presence of certain physical aspects such as secure walls, fencing and gates; buildings that are in a good state of repair; and well maintained school grounds. Safe schools are further characterized by good discipline, a culture conducive to teaching and learning, professional educator conduct, good governance and management practices and an absence, or low level, of crime and violence (Squelch, 2001:13).

While the task of creating safe schools involves educators, learners, parents and the broader community, this article forthwith places emphasis on the duties and liabilities of SGBs, which are most likely to be the target of lawsuits.

In the matter of Wynkwart ${ }^{41}$ the court stated that educators owe learners a legal duty to act positively to prevent harm being sustained. In this case a learner was seriously injured when he fell off an unused, locked gate at the school. The court a quo found that the DoE was liable for the injuries endured by the learner since the school failed to take reasonable steps to ensure the learners' safety. On appeal, the court placed prominence; not on foresee ability per se, but on what constitutes reasonable steps and whether such steps would have averted the harm.

With respect to the constant supervision of learners, the Court argued that the degree of supervision required depends on the risks to which learners are exposed. In deciding whether reasonable steps were taken, the court stated that due regard must be given to the circumstances of each case. In casu, reference was made to the age of learners and the possibility of only one learner slipping away. Since it was found that it was not reasonable to expect educators to constantly supervise learners, and that constant supervision would not have prevented injury to the said learner, it was concluded that the State was not to be held liable for the injury to the learner.

The court took the same stance in Rusere $v$ The Jesuit Fathers. ${ }^{42}$ It was noted that a contention to the effect that learners should never be more than momentarily out of sight of a responsible person even when they are in normal and familiar surroundings which are devoid of features that could sensibly be regarded as hazardous, is to exact too high a duty of care. Since learners (7-10

41 Minister of Education and another v Wynkwart NO 2004(3) SA 577 (C)

42 Ruserev The Jesuit Fathers 1970 (4) SA 537 (R) 
years of age) in casu were left totally unattended whilst engaging in a game with bows and arrows, the State was held legally liable for the injuries sustained by a learner. The State was equally held liable for injury endured by a learner in the matter of ewwis $^{43}$ due to the failure of the school to keep a school gate, which led to a busy thoroughfare, locked or efficiently latched.

Vicarious liability could also be incurred by the State for the conduct of third persons such as independent contractors. In this regard, Wicke (1998:612) shows that when the State employs another to, for instance, cut the grass or build classrooms some risk of harm to innocent third parties is created. An example of such vicarious liability occurred in the matter of Knouwds. ${ }^{44}$ A claim for damages to a learner, who fell on a lawnmower at school, was instituted against an independent contractor and the school principal as being jointly liable for unlawful actions on school grounds. While considering the different requirements for delictual liability, the court ruled that: the accident should have been foreseen by the supervisor and the operator as the possibility of learners colliding with the lawnmower was evident. Reference was made to the fact that a reasonable person would have taken precautions to avoid or prevent the damages. It was ruled that the risk to which the learners were exposed was such that constant supervision was necessary, and that since the staff did not reasonably guarantee the safety of the learners by exercising no supervision, the operator, supervisor and the principal were to be held jointly liable.

When damages, to the contrary, are sustained due to the negligence of an educator employed by the SGB (Schools Act: section 60(10)), the SGB per se will be held liable. This occurred in the matter of Ficksburg Primary School ${ }^{45}$ where damages were claimed for severe brain damage as a result of a learner nearly drowning whilst under the supervision of such an educator.

With further reference to the safety of learners, it was claimed in the matter of In Centre for Child Law \& others ${ }^{46}$ that the conditions at JW Luckhoff High School (a school of industry) infringed on the learners' constitutional rights (Constitution: sections 10, $12 \& 28$ ) in that it did not provide physical and psychological support structures. In its judgment the court stated that the duty to provide care and social services for learners placed at the school in terms of section 15(1)(d) of the Child Care Act, Act 74 of 1983 rested upon the State. As the purpose of schools of industry is to provide care and rehabilitation, it was concluded that secured environments, psychological, therapeutic and social support are critical ingredients of State care. The court, forthwith, set out that the justiciability of children's rights ought not to be comprised by budgetary considerations. In conclusion, it was found that budgetary-allocation problems were, in casu, far outweighed by the urgent need to advance the learners' interests in accordance with constitutional values. The State was, subsequently, ordered to provide the necessary support structures.

43 Carmathenshire Country Councilv Lewis 1855 (1) All ER 565 (HL)

44 Knouwds v Administrateur, Kaap 1981 (1) SA 544 (C)

45 Member of the Executive Council of the Free State for Education and Culture and Manda Louw (first respondent), and Martin Lourens Oosthuizen v Ficksburg Primary School. Highest Board of Appeal of South Africa. Case number 483/04 
Given the above-mentioned court rulings regarding damages to learners, it is not surprising that parents are viewing their concern over their children's' well-being while at school (Rapport 2009).

\subsubsection{Liability for school policies}

As stated before, the State and SGBs must always function within the parameters of the law. In the matter of Hoërskool Ermelo ${ }^{47}$ the Supreme Court of Appeal, accordingly, pointed out that all actions taken by the State involving schools have to comply with the principles of legality. Whether the DoE acted lawfully in changing the school's language policy, was to be decided in the matters of Mikro ${ }^{48}$ and Laerskool Middelburg. ${ }^{49}$ It was decided that the DoE act unlawfully in view of the best interests of the learners involved.

Whether the SGB, on the other hand, acted lawfully when compiling their school's language policy, had to be decided upon in the matter of Nkosi. ${ }^{50}$ As the language policy in casu resulted in the withholding of benefits to some learners, it was held to be of a discriminatory nature. In deciding whether the discrimination was fair or unfair, the court took into consideration that the school historically catered for English learners and that the overwhelming majority of learners spoke English as their home language. Having due regard to these facts, the court found that the discrimination suffered by the learner was fair, in all the prevailing circumstances. The same could, however, not be said of the discrimination suffered by the learner in relation to those learners whose home language was Afrikaans (equal amount of learners). As such, the court found that offering Afrikaans as a subject at a higher level that isiZulu composed unfair discrimination.

It was, however, also noted that the school could not be ordered to meet an ideal standard that no school could practically meet.

Although the Schools Act endeavours for learners, parents, educators and the State to accept responsibility for the governance of public schools in partnership with each other and not in litigious opposition to each other, the discussion above shows that the latter is more true in practice.

\section{Conclusion}

Whilst grasping the problems linked to the liability of public schools it became evident that good governance relies on consultation and positive action plans involving all role-players. School governance is, thus, not simply about ruling schools, but rather about removing barriers preventing the creation of effective education to all and to cooperatively deliver sound education

\footnotetext{
$47 \quad$ See fn 18

48 See fn 6

49 Laerskool Middelburg v Departementshoof, Mpumalanga Departement van Onderwys 2003 (4) SA 160 (T) 171A [also reported at [2002] 4 All SA 745 (T) 
policies. Democracy demands that differences be confronted and discussed thoroughly - it cannot be ignored - in order to reach consensus.

Legislation provides parents, educators and senior learners, as democratically elected members of SGBs, the opportunity to make their voices heard. SGBs must take up their rights, become active partners and, as such, gain experience and knowledge on how to govern schools effectively in the best interests of all learners. In so-doing, the State will come to respect them, realize that they are a growing force to be reckoned with and that it cannot unilaterally dictate the future of schools.

In collaborating with, inter alia, FEDSAS and numerous already effective SGBs, all schools can have SGBs that carry out their functions in a legally sound and accountable way whilst taking responsibility for their actions.

Justice, democracy and accountability, however, remain complex ideals and, as such, it must be realized that participation in school governance will not be without challenges. Of particular interest in this regard is how the mélange of SGBs and departmental institutions should interact and interrelate to influence the content, operation, performance and effectiveness of these institutions.

Seeing that the concept of SGBs is still relatively new, differences regarding the statutory functions, responsibilities and liabilities will exist and Courts will have to intervene. The complexity of school governance is demonstrated by the fact that the majority of court cases concerning school governance followed the route of appeals and reviews. Even courts, having the necessary legal expertise, hold opposing views in their interpretation of statutory provisions. SGB-members and the State must, hence, not be frustrated by differences and mistakes made, but rather be encouraged to take ownership of education.

Although legislation, with specific reference to the Schools Act, is far from perfect, a basis is laid for role-players to cooperate and to jointly take responsibility. Within this framework, section 60 of the Schools Act must not be regarded as merely bringing financial relief to SGBs or placing more pressure upon them to operate within the parameters of the law, but rather as the State embracing SGBs in their strive to better education. As such, it is essential that educational roleplayers take hands in order to, as set forth by Zuma, turn schools into thriving centers of excellence.

\section{References}

Basson, A. (2003). Vakbond maan teen lollery met kies van skole-rade. Beeld, 22 Sep.

Beckmann, J. (2006). The state's liability for damage or loss in connection with educational activity in public schools: recent minor judgments. Perspectives in Education. Vol 24(2). p. 181.

Beckmann, J. \& Prinsloo, I. (2009). Legislation on school governors' power to appoint educators: friend or foe? South African Journal of Education. Vol 29:171-184.

Bray, E. (2002). The constitutional concept of co-operative government and its application in education. THRHR. 65(4), Nov. pp. 514-531. 
Clase, P., Kok., J. \& Van der Merwe, M. (2007). Tension between school governing bodies and education authorities in South Africa and proposed resolutions thereof. South African Journal of Education. Vol. 27(2) pp.243-263.

De Bruin, P. (2009a). Ouers dok onwetend so op vir versekering. Beeld. 8 Jul.

De Bruin, P. (2009b). Hoofregter moet nou besluit of skole vrygestel is van eise. Volksblad. 6 Apr.

De la Harpe, S., Rijken, C. \& Roos, R. (2008). Good governance. P.E.R. Volume 2.

Du Toit, P. (2007). Skooltaal beïnvloed rassesamestellings. Beeld. 3 Mar.

Fareed, F. \& Waghid, Y. (2005). In defense of deliberative democracy: challenging less democratic school governing body practices. South African Journal of Education. Vol 25(1). pp.25-33.

FEDSAS: Federation of Governing Bodies of South African Schools. (2002). FEDSAS' submission on the Education Laws Amendment Bill. Government Gazette, No. 23327.

Foster, W.F. \& Smith, J. (2001). The Governance of Education in South Africa: An Analysis of the Legislative Framework. Montreal: CSAEMP Publications.

Gamage, D. (1994). School governance. (In Thody, A. (ed.). (1994). School governors: leaders or followers? Essex: Longman. pp. 45-46).

Gouws, P. (2001). Nood in spesiale skole; geld en personeel gesny. Rapport (Gauteng) 28 Oct.

Harber, C. (2005). Markets, equity and democracy - structural adjustment and the tensions of educational change in South Africa. L Chisholm - State of the nation: South Africa 20042005, 2004 - books.google.com. Date of access: 26-05-2009.

Heystek, J. (2004). School governing bodies - the principal's burden or the light of his/her life? South African Journal of Education. Vol. 24(4) pp. 308-312.

Hoffman, R. (2009). We expect a high turnout. The Teacher. 23 Jun.

Karlsson, J. (2002). The role of democratically elected governing bodies in South African schools. Comparative Education. 38(3):327-336.

Kuye, J.O. \& Kakumba, U. (2008). Development initiatives and global governance: a continental perspective. Journal of Public Administration. 43(4.1). Dec. pp. 631-645.

Mabasa, T \& Themane, J. (2002). Stakeholder participation in school governance in South Africa. Perspectives in Education. 20(3), Sep. pp. 111-116.

Mabovula, N. (2009). Giving effect to the voiceless through deliberate democratic school governance. South African Journal for Education. Vol. 29. pp. 219-223.

Maile, S. (2002). Accountability: an essential aspect of school governance. South African Journal of Education. Vol. 22. pp.326-331.

Marope, M. \& Sack, R. (2007). The pedagogy of education policy formulation: working from policy assets. Perspectives in Education. 25(1). pp. 11-30.

Mestry, R. (2006). The functions of school governing bodies in managing school finances. South African Journal of Education. 26(1). pp.27-38.

Mncube, V. (2009). The Perception of parents of their role in the democratic governance of schools in South Africa: are they aboard? South African Journal for Education. Volume 29 (1). pp. 83-104. 
Ngidi, D.P. (2004). Educators' perceptions of the efficiency of school governing bodies. South African Journal of Education. 24(4). p. 260-263.

Oelofse, L. (2003). Owerheid moet na ouers luister oor aanstellings, beslis hof. Rapport. 11 May.

Pearmain, D.L. (2006). Contracting for socio-economic rights: a contradiction in terms?. THRHR. 69(2) May. pp. 287-301.

Pennefather, J. (2008). Rural schools and universities: the use of partnerships as a teaching strategy in enhancing a positive response to rurality. Perspectives in Education, 26(2) Jun. pp. 81-94.

Probyn, M., Murray, S., Botha, L., Botya, P., Brooks, M. \& Westphal, V. (2002). Minding the gaps - an investigation into language policy and practice in four Eastern Cape districts. Perspectives in Education. Vol 20(1). pp. 2-9.

Rademeyer, A. (2009). Vakbond saai chaos by skole. Beeld. 4 Jun.

Rapport . (2009). Ouers het lys van klagtes oor skool. 15 May.

Roos, R. (2003). Legal requirements for school rules and disciplinary sanctions. Koers 68(4) 2003:481-498.

Shaba, S. (2000). Keynote address at the Conference on Health and Safety in Schools held 4-6 Sep. 2000 hosted by RAU at Kopanong Hotel, Benoni.

Schelder, A., Diamond, L. \& Platter, M.A. (1999). The self-restraining state. Power and accountability in new democracies. London: Lynne Riener.

Singh, P., Mbokodi, S.M. \& Msila, V.T. (2004). Black parental involvement in education. South African Journal of Education. Vol 24(4). pp. 301-307.

Squelch, J. (2001). Do school governing bodies have the duty to create safe schools? An education law perspective. Perspectives in Education. Volume 19(4) 2001.p.13-17.

The Teacher reporter. (2009). Our schools will be centers of excellence, says Zuma. 3 Jun.

Tsotetsi, S.,Van Wyk, N. \& Lemmer, E. (2008). The experience of and need for training of school governors in rural schools in South Africa. South African Journal of Education. Vol. 28. pp.385-400.

United Nation's Commission for Global Governance. Good Governance Practices for the Protection of Human Rights. United Nations ISBN 9789211541793. pp. 84.

United Nations. Towards Inclusive Governance: Promoting the Participation of Disadvantaged Groups in Asia-Pacific. United Nations' Development Programme (UNDP) ISBN 9789740628378.

Van Aswegen, A. (1997). Professional liability to clients: the implications of concurrence. THRHR. 60(3). Aug. pp. 395-411.

Van Rooyen, M. (2009). Stof wil maar nie gaan lê oor taalkwessie by skool. Volksblad. 1 May.

Van Wyk, N. (2001). Preparing South African educators for school-gamily-community partnerships. Educare,30(1). pp.115-139.

Van Wyk, N. (2004). School governing bodies: the experiences of South African educators. South African Journal of Education. 24(1). pp. 49-54.

Visser, P.J. (1998). The admission of learners to public schools: who makes the decisions? TD, 6(1), July 2010, pp. 93 - 112. 
THRHR. 61(3), Aug. pp. 487-491.

Visser, P.J. (2003). Notes on the contractual capacity of the governing body of a public school and related issues. THRHR. 66(1) Feb. 2002. pp. 111-115.

Visser, P.J. (2006). Education law - Language policy at single-medium public school - section 29(2) of the Constitution - irregular interference by Provincial Education Department. THRHR. 69(2). May 2003.

Volksblad. (2005). Beheer oor onderwys. 18 May.

Wicke, H. (1998). Vicarious liability for agents and the distinction between employees, agents and independent contractors. THRHR. 61(4) Nov. pp. 609-623.

Xaba, M.I. (2004). Governors or watchdogs? The role of educators in school governing bodies. South African Journal of Education, 24(4) pp. 313-316.

Legidslation

SOUTH AFRICA. 1983. Child Care Act, Act 74 of 1983. Pretoria: Government Printer.

SOUTH AFRICA. 1988. Education Affairs Act, 70 of 1988. Pretoria: Government Printer.

SOUTH AFRICA. 1996. Constitution of the Republic of South Africa, Act 108 of 1996 as adopted by the Constitutional Assembly on 8 May 1996 and as amended on 11 October 1996. (B34B-96) (ISBN:0-260-20716-7)

SOUTH AFRICA. 1996. South African Schools Act No. 84 of 1996. Pretoria: Government Printer. 